\title{
A Survey of Literary Level - a Case Study of Sayed Mohammad Taheri Shahab
}

\author{
${ }^{1}$ Farnaz Sameni Keivani, ${ }^{2}$ Pouran Alizadeh \\ ${ }^{I}$ Department of Persian Language and Literature, Rasht Center, Payame Noor University, Rasht, Iran \\ ${ }^{2}$ Department of Persian Language and Literature, Roudsar and Amlash Branch, Islamic Azad University, \\ Roudsar, Iran
}

\begin{abstract}
This study examines the literary level of Sayed Mohammad Taheri who also is called Shahab. He was living in Sari city in Iran in 1295. He has written many books and papers in period of his lifetime. This study investigates literary level of that poet by reviewing his works. In fact, it illustrates his expression level of the poet by looking at his works. Hence, the findings of this paper create a good vision for better recognition of Shahab and also it helps us to do other research about this poet. It also enriches the literature about this matter. Here, it can suggest the researches like this about other famous poets or develop for Shahab.

Key Words: Expression science, poet, Literary, the Literature Level, Taheri Shahab and Iran
\end{abstract}

\section{Introduction}

The meaning of expression science is unfold or revealing and in Phrase is defined as a collection of rules and terms a word is shown in some different ways by using those rules. In fact, a poet uses expression science in order to create a nice picture in the readers' minds and encourage them to read all of things who written. One of the poets who use the expression science is Sayed Mohammad Taheri Shahab. He was born in Sari on 1295 and he died in 1971.In fact, he is a poet in the contemporary period. First, Taheri Shahab studied at a school in Sari. After graduating the primary school, he went to Tehran and Qhom. After completing his study, he came back to Sari. He was working at the civil registration office as a government employee, besides of scientific and literary activities. Some years after his father's death, he removed that occupation. In fact, Taheri Shahab is one of the most famous researchers in Mazandaran province. He applied the restoring some of the texts and also the introduction of Mazandaran celebrities. Writing of precious works makes him as a great famous of Iran after. Hussein Towfiqh was a journalist who trainers and encourages Shahab. In 1952, Shahab owned the Journal royalty of Far Iran. He established a literary association with supporting some his friends in Sari at 1954. He attended the literary association of Hakim Nazami Tehran since 1962. Taheri Shahab has written many books and articles during his lifetime. They are classified to five groups as there are following: other papers on this subject include [30-38]:

1- Poems

2- Articles in the journals

3- Books and translation effects

4- the manuscripts of collected

5- Correcting of texts

\section{Expression science}

Expression science, in Persian language is called Bayan, means that finding, unfold or revealing and in Phrase is defined as a collection of rules and terms a word is shown in some different ways by using those rules. In other words, expression science is a science that we can express the meaning of a word to some various ways using that science. In fact a poet communicates the surrounding things with a different vision. He or she discovers the relationships between things which they are his or her surroundings using his or her imagination. Imagination or image is a result of experience which it is often associated with a background of emotional. Poetic experience isn't a result of poet volition. It is a spiritual event that is unconsciously in his mind. Four main topics of this science are: Simile, metaphor, allusion and authorized. Issues of this science are considered as Inherent in literary texts. Because, there is not any literary work which it be completely devoid of them. Indeed, this tool of expression is that causes the poet's words are nice and it effect to the hearts of readers. Briefly, in order to make the poets like a beautiful painting in the minds of the readers and increase the sweetness of his words and avoid from the repeat rule which it makes the readers be exhausted a poet uses the expressive images in his or her poems. 


\section{The poems forms of Tahiri Shahab}

Form means that framework which it synonyms are the shape, and structure. It is a phrase in literary criticism. In fact, it is a shape that the poet content and ideas are crystallized in it. The form and content appear together in the text. Each text chooses normally it suitable form. Finally, the poetic form must be proportional with the content, wording and intention of the poet. Because of it plays a decisive role to express the meaning. The form of a poem causes that the reader expects a particular landscape in his poetry. Indeed, the poems form portrays spontaneously the announcer special features as soon as the poem is reading to readers. In the investigated collection of Taheri Shahab, we can see more or less all of the poetry traditional forms.

\section{1-1. the Types of the Likened:}

\begin{tabular}{|c|c|c|c|c|c|}
\hline Metonymy & Detailed & Eloquent & Synopsis & Emphatic & Type of likened \\
\hline 429 & 619 & 656 & 737 & 927 & Abundance \\
\hline $31 \%$ & $45 \%$ & $48 \%$ & $54 \%$ & $68 \%$ & Percent \\
\hline
\end{tabular}

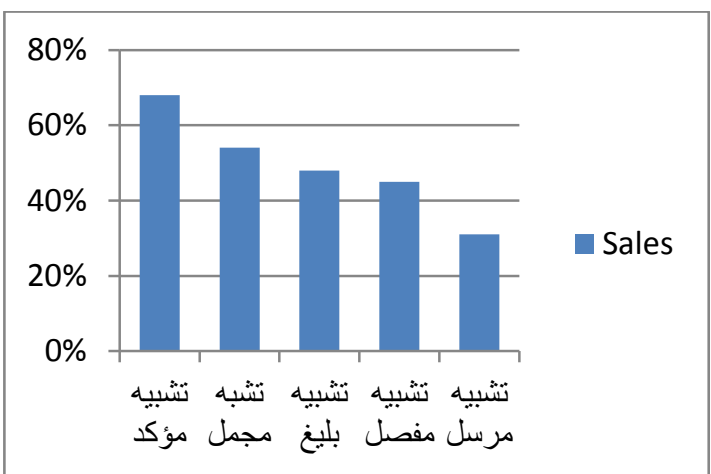

1-2 likened respect to the validity of sensory and intellectual

\begin{tabular}{|c|c|c|c|c|}
\hline $\begin{array}{c}\text { Reasonable to } \\
\text { Reasonable }\end{array}$ & Tangible to reasonable & Reasonable to tangible & Tangible to tangible & Type of likened \\
\hline 25 & 72 & 561 & 698 & Abundance \\
\hline $2 \%$ & $6 \%$ & $42 \%$ & $50 \%$ & Percent \\
\hline
\end{tabular}

1-3. all of types likened in shape

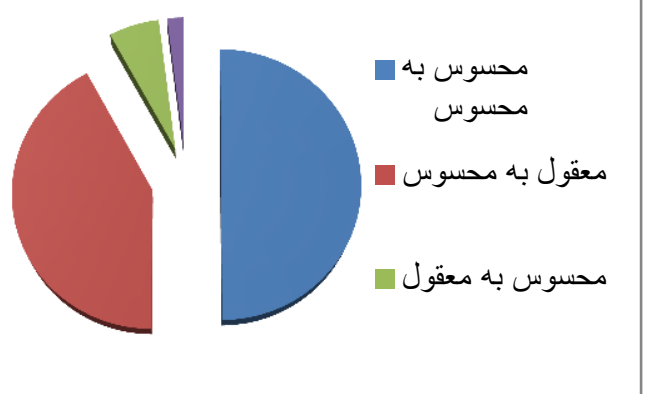

\begin{tabular}{|c|c|c|c|c|c|c|c|}
\hline Malfoof & Settlement & Conditional & Subtrahend & Detail & total & $\begin{array}{c}\text { Implicated } \\
\text { likened }\end{array}$ & Abundance \\
\hline 3 & 6 & 6 & 15 & 20 & 22 & 42 & Abund \\
\hline $2 \%$ & $5 \%$ & $5 \%$ & $13 \%$ & $18 \%$ & $19 \%$ & $37 \%$ & Percent \\
\hline
\end{tabular}

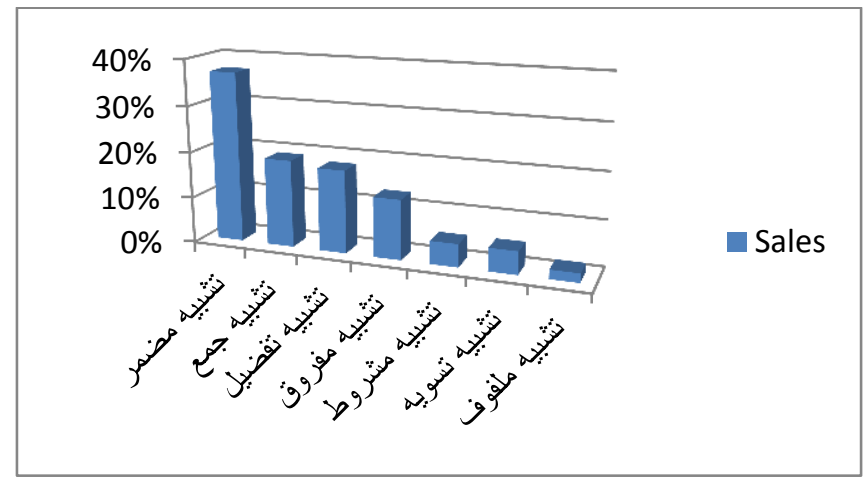


1-4 Likened to the validity of the singular and combined

\begin{tabular}{|c|c|c|}
\hline Compound to compound & Singular to Singular & Type of likened \\
\hline 20 & 1336 & Abundance \\
\hline$\% 2$ & $\% 98$ & Percent \\
\hline
\end{tabular}

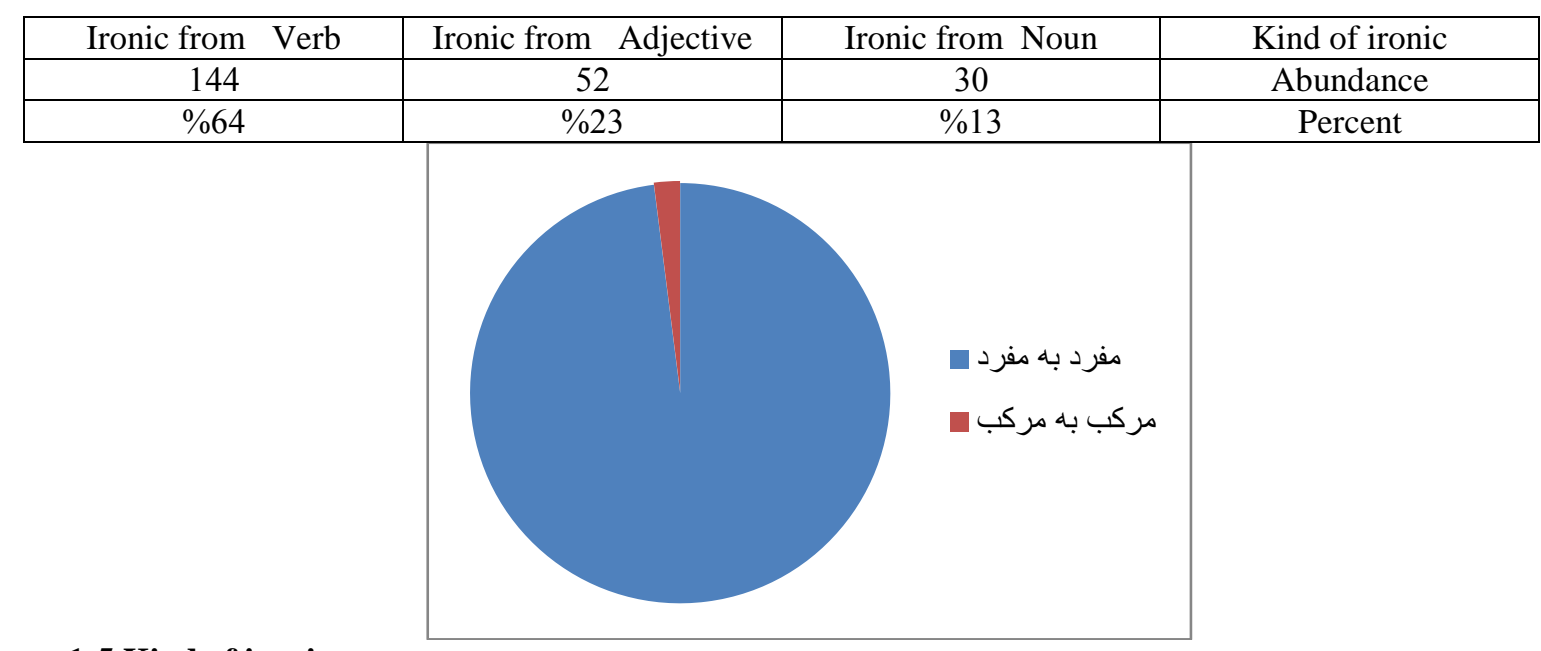

\section{1-5 Kind of ironic}

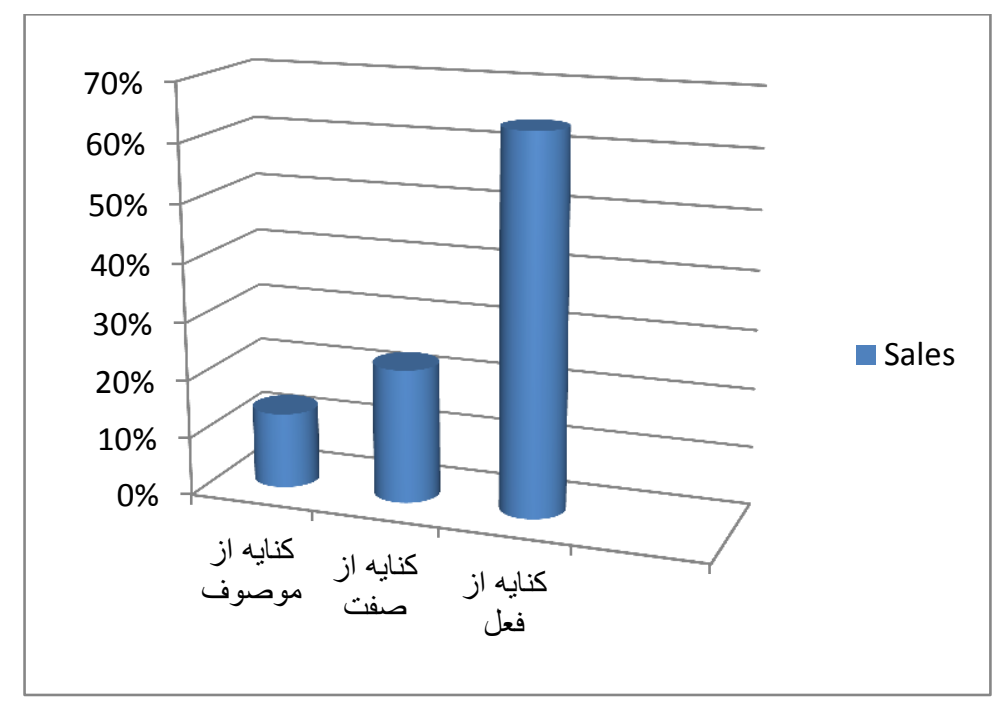




\section{1-6 Kind of arrays}

\begin{tabular}{|c|c|c|}
\hline Conflict & Licensed & Kind of arrays \\
\hline 669 & 108 & Abundance \\
\hline$\% 86$ & $\% 14$ & Percent \\
\hline
\end{tabular}

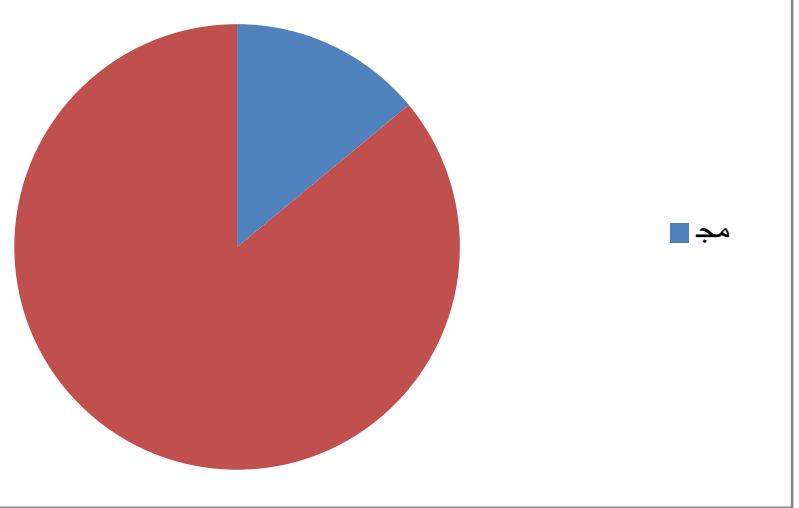

\section{1-7. Types of Metaphor}

\begin{tabular}{|c|c|c|}
\hline Makanniyeh & Stipulated & Types of Metaphor \\
\hline 162 & 237 & Abundance \\
\hline$\% 40$ & $\% 59$ & Percent \\
\hline
\end{tabular}

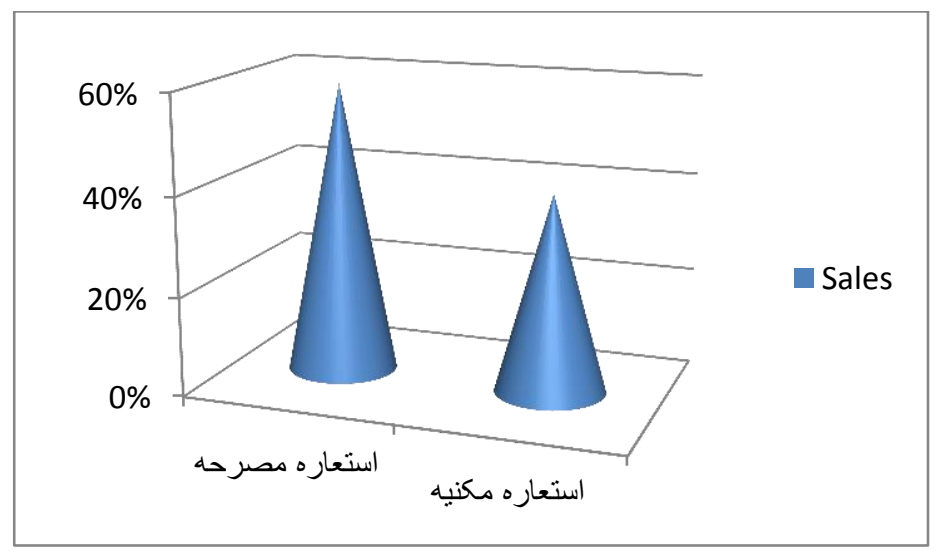

\section{References}

[1] Alborz, Parvez, (2002), a step in the realm of poetry and music, Tehran, An Publication

[2] Abbasi, Habib, (2008), Safarnamh Baran, Tehran, Sokhan Publication

[3] Alipour, Mustafa, (2001), the structure of the contemporary poetry, Tehran, Ferdows Publication

[4] Ahmadinejad, Kame, (1993), Literary Techniques, First Printing, Tehran, Paya Publication

[5] Anousheh, Hassan and others, (1997), Encyclopedia of Persian literature, vol 2, Tehran, Daneshnameh Publication

[6] Behzadi Andovhajradi, Hussain, (1996), literary techniques and arrangements, First Edition, Tehran, Islamic Azad University Publication

[7] Farshidvard, Khosroo, (1984), about literature and literary criticism, vol 1, Tehran, Amir Kabir Publication

[8] Fesharaki, Mohammed, (2006), Badih criticism, Second Edition, Tehran, Studies and Writing Institute of human sciences Books or SAMAT

[9] Fayyazmanesh, Parand, (2005), other view music, poem and its link with subject of poetic imagination, Journal of Persian Language and Literature - Issue 5

[10] Hadi, Rohollah, (1996), literature Arrangement, Tehran, Chap va Nasher Iran

[11] Homaei, Jalaluddin, (1996), techniques of literary rhetorical, Tehran, Homa

[12] Jahantigh Khalili, Maryam, (2001), the Apple of Baghjan, Tehran, Agah Publication

[13] Jalali, L. and Sameni Keivani. Farshad, an Investigation of Historical Geography, 11(5) IOSR Journals of Humanities and Social Science (IOSR-JHSS) e-ISSN: 2279-0837, p-ISSN: 2279-0845. Volume 17, Issue 2 (Nov. - Dec. 2013), PP 26-30 
[14] Jalali, L. and Farshad Sameni Keivani, (2013), An Investigation of Historical Geography of Shahindezh Region, Journal of Applied Environmental and Biological Sciences, text road, ISSN 2090-4274, 3(12)34-38

[15] Kashefi Sabzwari, Vaez, (1990), Bedayeh Alafkar, Tehran, Nashr Markaz Publication

[16] Kazzazi, Mirjalallodin, (2002), Aesthetics of Persian speak (3), Tehran, Nashr Markaz Publication

[17] Mohammadi, Mohammad Hussein, (1995), Alien like Meaning, Tehran, Mitra Publication

[18] Norouzi, Jahanbakhash, (1993), jewelery of speaks and Persian poem species, Tehran, Rahgosha Pubication

[19] Pournamdarian, Taghi, (2002), Trip in Mount, Tehran: Agah Publication

[20] Rajai - Mohammad Khalil, (1980), Malem Balaghah in semantics and expression of a novel, Third Edition, Shiraz, University Publication

[21] Sameni Keivani, Farnaz, (2013), Sayed Mohammad Taheri Shahab, Master's thesis, Payam Noor University, Rasht Center, Iran

[22] Shafie kadkani, Mohammad Reza, (1989), Music of poem, Second Edition - Tehran: Agah Publication

[23] Shafie kadkani, Mohammad Reza, (2001), periods of Persian poem, Tehran, Sokhan Publication

[24] Shamsaldin, Qais Razi, (1994), Almajam, with helping of Cirrus Shamisa, Tehran, Ferdows Publication

[25] Shamisa, Cirrus, (1990), Culture allusions, Tehran, Mitra Publication

[26] Shamisa, Cirrus, (1991), Badih, Third Edition, Tehran, Payam Noor Publication

[27] Shamisa, Cirrus, (1991), new look to Badih, Third Edition, Tehran, Ferdows Publication

[28] Shamisa, Cirrus, (1994), General of Stylistics, Tehran, Ferdows Publication

[29] Shamisa, Cirrus, (2004), Types of Literary, Tenth Edition, Tehran, Ferdows Publication

[30] Shamisa, Cirrus, (2007), words and meanings, Tehran, Ferdows Publication

[31] Shamisa, Cirrus, (2008), Expression, Third Edition, Tehran, Publication Mitra

[32] Tajlil, Jalil, (1993), pun in Persian literature, Second Edition, Tehran, Institute for Cultural Studies and Research

[33] Tajlil, Jalil, (1997), meaning and expression, Eighth Edition, Tehran, Academic Publication

[34] Tajlil, Jalil, (1999), prosody and rhyme, First Printing, Tehran, Sepehr Kohan Publication

[35] Vahidian Kamyar, Taghi, (1995), Persian poetry Rhyme, Tehran, Center for Academic Publication

[36] Valek, Reneh, Waran Avastan, (1994), Theory of Literature, translated by Movahed and Mohajer, Tehran, Scientific and Cultural

[37] Yahaghi, Mohammed Jafar, (1996), like jug Thirsty, history of Persian contemporary literature, Tehran, Chap Neil Publication

[38] Zarrinkoub, Abdulhussain, (1984), the poetry no mask and no lies, Tehran, Javidan Publication 